\title{
Does screendance need to look like dance?
}

\author{
Claudia Kappenberg University of Brighton
}

\begin{abstract}
This is an edited version of a paper, which was first presented at the American Dance Festival (ADF, 2008), Screendance State of the Art 2, Duke University, North Carolina, and re-presented at the symposium, Exploring the Screen as a Site for Choreography (2009), Department of Drama, Theatre, Film and Television, University of Bristol UK. Drawing on a wider field of visual art, film, dance and theatre studies, the article proposes a new knowledge map for screendance aiming to articulate the complexities of choreographic sensibilities and identifying a set of screendance strategies. The knowledge map adapts the Laban effort graph to layout a field that ranges from real time and real space to edited time and edited space, body as tool and body as site, thereby offering a more flexible and complex alternative to the existing mapping of screendance as videodance and cinedance.
\end{abstract}

\section{Introduction}

A growing number of international screendance conferences over the last decade are evidence of an interest in and preoccupation with a theorization of screendance.

However, the debates have been limited by a lack of differentiation of practices within the art form, and basic distinctions such as 'cinedance' and 'videodance' do not do justice to the complexities of the work. In order to facilitate a more effective reflection and critique, I will propose a new set of terms to foreground different historical roots, conceptual frameworks and methodologies. To begin, the article proposes the notion of 'dance as film' compared to 'dance for film' and reviews the history of these terms. The discussion then turns to a philosophical debate on artistic strategies in performance practices to deliberately expand from film and new media theories in search of an alternative framework for an analysis of screendance practice. Building on this discussion, the article presents a visual map or knowledge map that is based on the Laban effort graph, as a means to name and situate different choreographic sensibilities and processes. ${ }^{1}$ 
Whilst mapping a wide range of screendance practices, this article can only sketch some of the issues involved. Some readers may also expect a definition of screendance as part of a knowledge map, but this will not be given, in order to avoid limiting an art form, which builds on multiple histories and arts practices and which ought to expand on this hybridity. To draw on a definition of dance by Randy Martin in Critical Moves, I would merely say that screendance is a predicament, which occurs within a complex field of tensions (Martin 1998: 6). In much the same spirit, the editorial of Cairon 11 (2008), a Spanish magazine for Dance Studies, describes screendance as a mode of thought generated by at least two forms of writing, cinematography and choreography (Sanchez and Navaran 2008: 237, 238). The notion of 'dance as film' as discussed later will seek to clarify some of the thinking that is produced through these different forms of writing.

\section{Dance as film}

In the early 1980s, screendance artist Amy Greenfield published a statement in a catalogue for the 'Filmdance Festival' at the Public Theatre in New York City. In this statement, Greenfield argued that screendance did not need to resemble what we know as dance and that work ought to be made not for film but as film. She suggested that such work "may not "look like" a dance, but [...] has the kinaesthetic impact and meanings of dance' (Greenfield 1983: 26).

Some 20 years earlier, film-maker and theorist, Maya Deren had raised the same question in an essay entitled 'Cinema as an Art Form'. Reflecting on the often unsuccessful translation of stage-based dance to film, Deren had called for an art form which was conceived as cinematic art in the first place: 
There is a potential filmic dance form, in which the choreography and movements would be designed, precisely, for the mobility and other attributes of the camera but this, too, requires an independence from theatrical dance conceptions.

(Deren 1960a: 258)

Almost 30 years after Greenfield and 50 years after Deren, much of screendance remains rooted above all in dance traditions, and programming in screendance festivals rarely include works from other fields such as video art or experimental film. The home page for the annual 'Dance on Camera Festival' in New York demonstrates this legacy, stating that since its creation in 1971, its mission has been to facilitate the preservation of dance, encourage documentaries on dance and further screen adaptations. I would argue that all three categories are representative of a 'dance for film' approach in that the film-making and its technologies are predominantly put at the service of the dance. The 'Live Screen' events at Sadler's Wells, London, are an example of a curation that breaks away from narrow conceptions of screendance, as well as 'MOVES, Movement on Screen', a film festival in Manchester founded by Pascal Moyse in 2005. The title of this festival references the broader notion of 'movement' instead of 'dance' to embrace a wider moving-image-based practice, just as 'Live Screen' avoids any mention of dance and frames the work instead as a combination of live and screen-based practices. In a paper at Screendance State of the Art (2006), Douglas Rosenberg proposed a 'What if' paradigm as a curatorial framework that would allow a wide range of work to be screened and recontextualized within a screendance context (Rosenberg 2006: 15, 16). Initiatives of this kind expand the field and address a different kind of audience. To support such developments a wider review of the notion of 'dance as film' is due. 


\section{Historical legacy}

The attachment to, and reproduction of, familiar forms of dance within screendance is due to a complex historical trajectory which saw, on one hand, a critical stance towards the mediation of dance through technology and, on the other, a legacy of primarily Hollywood cinema, when dance was indeed made for film. In this constellation the choreographing is a separate process to the film-making with a dance already made before the technology mediates. Subsequently, those critical of technology have argued that technical intervention can distort the dance and lose what the dance could on its own provide. Sherril Dodds explores the continuation of this legacy in her book Genres and Media from Hollywood to Experimental Art (2001). She quotes, for example, the critic Sacks, who said in 1994 that 'Dance and film are inherently incompatible, film is realistic, dance unrealistic' (Dodds 2001: 16). The comment indicates that screendance was, and is, not necessarily seen as its own art form but rather as a more or less successful rendition of dance via film. Furthermore, a limited vocabulary for the discussion and critique of such work has continued to tie screendance practitioners and ambassadors to the pre-existing disciplines. Dodds, for example, speaks of a 'televisual mediation of dance', a term which replicates a division of processes into two parts whereby the body provides the dance while the technology does something else like mediation, representation or framing (Dodds 2001: 27).

Fierce resistance to a different, experimental filmic dance form is of course only one half of the (his)story of screendance. At the other end of the spectrum, we find screen-based works with no evidence of a duality between dance and technology. An early example of a different sort of choreographic cinematography is the film Entr'Acte by Dada artist René Clair from 1924, a hilarious and irreverent collage of 
scenes, which begins with two men playing chess on the rooftops of Paris and leads to the chase of a funeral hearse that is drawn by a camel and ends in a field where the dead man jumps out of the coffin and makes everyone disappear from the scene. The work is a fast-paced combination of cinematographic magic and surreal imagery, whereby the choreography is created through camera movements, expressive and surreal movements of the protagonists and edited to create a space-time that can only exist on screen. Ann Cooper Albright argues in a paper from 2006 that Loïe Fuller's Le Lys de la Vie from 1921 should also be mentioned here because of its inventive exploration of movement through body, costume and light. This work is little known but constituted a significant development at the time and may have been an inspiration for René Clair (Cooper Albright 2006: 27).

Many other artists and film-makers could be listed under a heading like filmdance choreography, including Lotte Reininger, Fernand Léger, Len Lye, Oscar Fischinger, Maya Deren, Shirley Clarke, Stan Brakhage, Hilary Harris, Amy Greenfield, Margaret Tait, Jayne Parker, Sergei Parajanov and Zbig Rybczynski, to name a few from across different decades and continents. ${ }^{2}$ In the works of these artists the dance is not located in, or limited to, a particular dancing body or a set of movements, but the work as a whole is engaged, somewhat like the quality of lines in a Giacometti drawing, which does not change between the figure and the background. Interested in the artistic potential of the moving-image technology, the magazine Ballet International/tanz aktuel ran an interview with the Italian critic Elsa Vaccarino in 1979, who strongly endorsed screendance as an experimental and pioneering art form. Whilst considering the opinions of both enemies and friends of the technological mediation of dance, she argued that, 'dance is the ideal go-between for 
electronic and real bodies' and 'dance has stimulated their makers to seek new solutions and creations in the technical/expressive modalitie

s of video' (Vaccarino 1997: 8, 9). Her comments emphasize the possibilities inherent in a hybrid practice to develop new approaches across different art forms.

A symposium in Bristol in April 2009, which explored the screen as a site for choreography, showed works by Becky Edmunds, Lucy Cash, Bert Gottschalk, Jamin Winans, Jeff Chiba Sterns and Christopher Steel, all of which combined live and mediated elements in a way that 'the dance' or rather the choreography was inseparable from the cinematography. In Edmunds's On the Surface (Edmunds 2007a), a single slow zoom creates a dynamic, by which a person disappears on the horizon as the camera embraces more and more of the landscape. In Gottschalk's Framing/Fensterbilder (Gottschalk 2007), a cinematographic choreography is created through series of windows and details of hands, which pass through the frame in elegant changing patterns (see Figure 1 and 2).

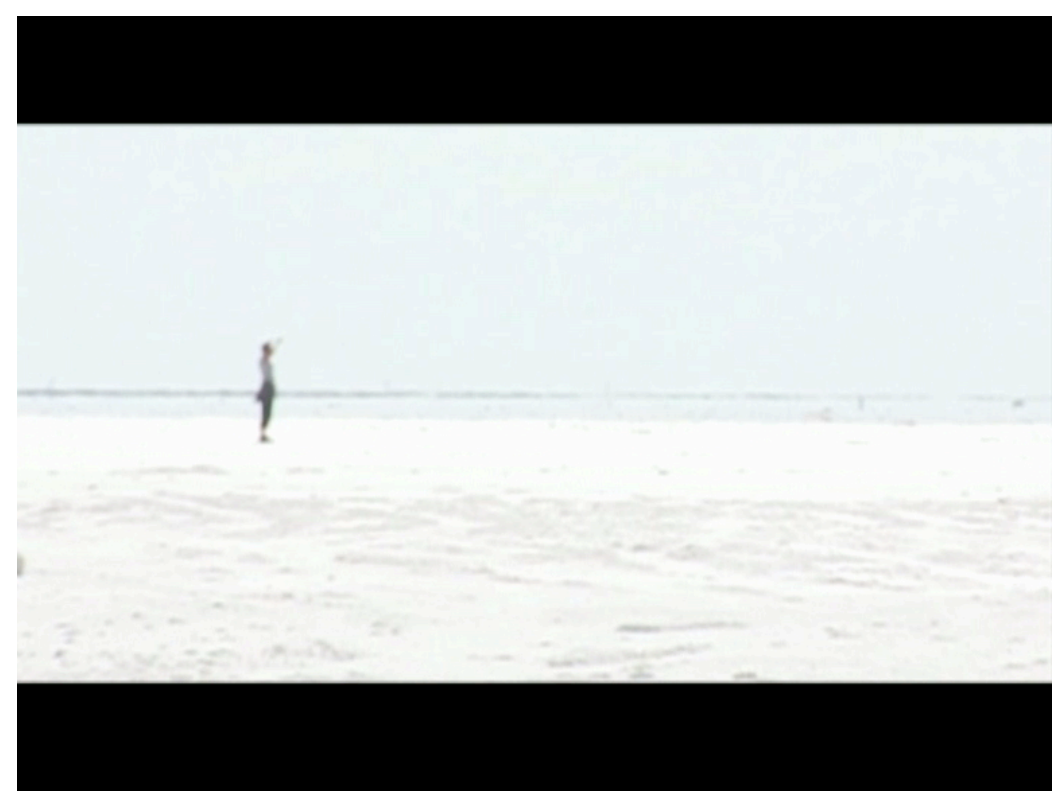

Figure 1: Screen shot of On the Surface (Edmunds 2007a). 


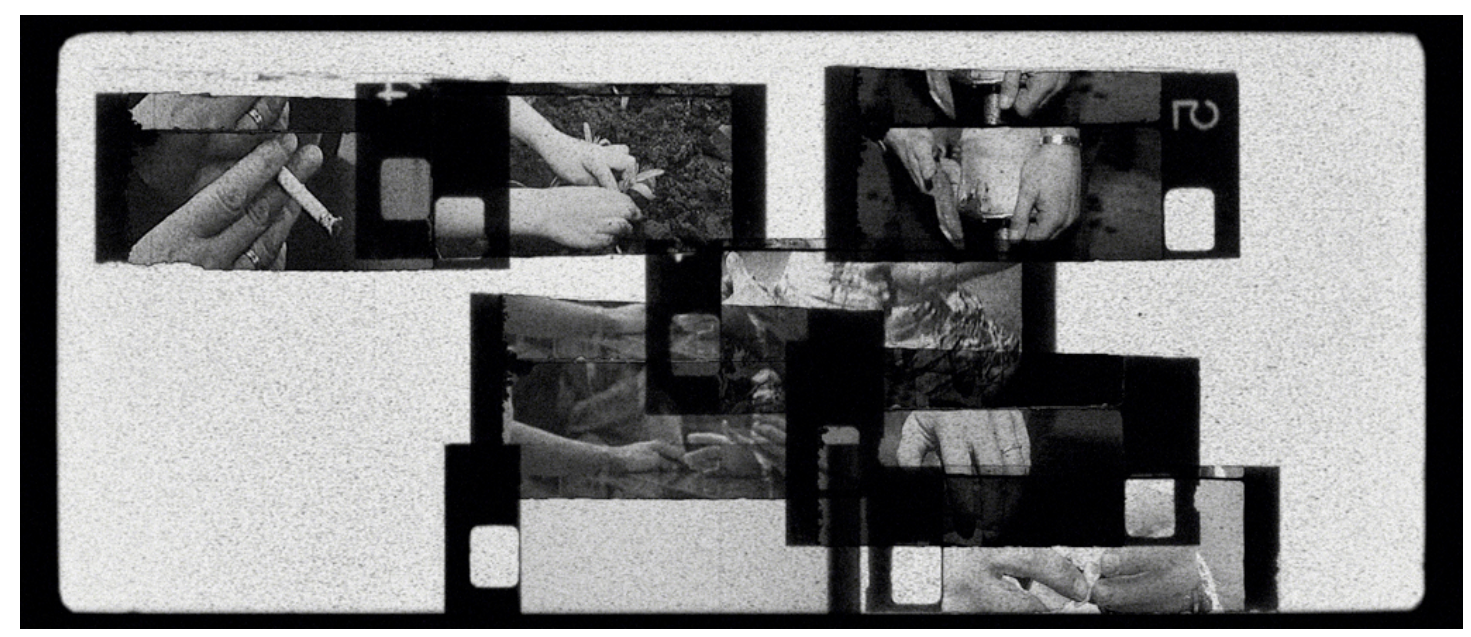

Figure 2: Screen shot of Framing/Fensterbilder (Gottschalk 2007).

In these works, artists combine live bodies and technical bodies, live and mediated processes and real and digital space in ever more complex configurations. New creative possibilities and new working methods have emerged through new technologies, more or less sidestepping the traditional production processes of television and cinema from script writing to funding constraints and dependencies on producers, commissioners and programmers. With this proliferation of practices and platforms, there is an even greater need to expand the vocabulary of screendance. A lack of means to adequately describe the work or to distinguish between different kinds of screendance is a linguistic as well as a conceptual issue and a more precise archaeology of the art form is called for not least to further contemporary critical debates.

\section{Classification, genres and strategies}

A discussion of the notion of genres will serve to clarify what the term may or may not offer to a critical debate. This will include a brief review on the process of 
categorization and theorization of practice to lay a critical framework for a subsequent mapping of screendance practices.

The discussion draws on an essay by Tobin Nellhaus, published in Staging Philosophy (2006), a collection of interdisciplinary essays. Nellhaus is concerned with theorizing the basic dynamics that lead to the formation of different forms of a performance practice and offers a model, which is also relevant for this discussion of screen-based work. Nellhaus writes from a perspective of 'critical realism', a branch of philosophy, which was originally developed in the 1930s and which recognizes that a reality exists independent of us. Critical realism differentiates itself on one hand from positivism, which makes reality dependent on our experience and perception of it, and on the other hand from postmodernism, which discusses the social and cultural fabric as text, making language the determining factor (Nellhaus 2006: 57, 58, 61). Critical realism understands society instead as a totality made up of at least three main strata, which can be represented by a pyramid composed of basic structures, agents and discourse. Critical realism proposes a multitude of causal relations between things as the elements of each layer act on those in the other layers (Nellhaus 2006: 59, 60).

In addition the strata model allows for the notion of emergence. Emergence means that one term may arise out of another and act on the first but is irreducible to it (Nellhaus 2006: 60). The concept of emergence is useful to describe in general terms the relation of theory to practice; theories are emergent properties of practices, they may arise from a practice and act on it, but are not reducible to it. We can also invert this statement; that is practices are emergent properties of theories, arise from theories and act on these, but are not reducible to them (Nellhaus 2006: 64). The notion of emergence establishes a fluid ground and allows classifications to be formed and reformed in an ongoing dialogue between theories and practices. 
Without going any further into the complexities of 'critical realism', I will focus in the following on Nellhaus's debate on genres, which rests on the model of strata and their interactions. Many art forms have well-established genres often built on likeness, classifying work through a number of factors such as content, formal aspects and the materials used, by the traditions they draw on or by production and viewing context. A discussion of genres for screendance is central to Dodds's Dance on Screen mentioned earlier. Dodds identifies several genres, namely Hollywood dance film, television advertising, music videos and video dance, while the latter is sited within the television industry as a hybrid between postmodern stage-based dance and television, and does not cross over into the visual art world and the gallery space.

Nellhaus questions the usefulness of genres in the context of his debate on performance practices. He argues: 'genre [...] is basically a formal or stylistic notion. It functions on the discursive level alone [...] and may not be effective for understanding (say) the nature of comedy as such' (Nellhaus 2006: 80, 81). While Nellhaus doubts the analytical capacity of such terms, the list of genres for screendance as proposed by Dodds reflects important historical developments of screendance. The genres are indeed predominantly formal groupings, indicating production context and relevant forms of dissemination or materials used such as video or film. The genres are, however, characteristic of a discourse on screendance, which has tended to focus on modes of production and distribution and which testifies to the dominance of the industry on the field altogether.

Following this analysis we can ask, for example, what other sets of categories could lead to the identification of other aspects of screendance practices, to reveal their 'underlying conceptual level', as Nellhaus puts it (Nellhaus 2006: 79). His concern is to come up with a system of classification that recognizes and empowers 
artists or agents, and the exercise of agency. He therefore proposes the notion of 'strategy' to be able to analyse and name the dynamics at the heart of a practice.

Describing artists as agents, he writes:

agents devise [plans] to achieve certain goals, solve certain problems, and answer certain questions about what it is to be an agent. [...] Agents form strategies to cross the divide between intention and present condition, to struggle with and change realities. [...] Strategies involve an overarching goal, a plan for achieving it, and intermediate steps requiring particular measures.

(Nellhaus 2006: 78)

On the basis of the model of the world that critical realism provides, Nellhaus wants creative strategies to reflect on the entire complexity of the multiple strata in order to empower the artist and maker. This approach appears useful in the context of screendance as it would place the work and its maker firmly into a social and historical context. The naming of such strategies might ease the path to the identification of issues in work or facilitate a more engaged screendance practice addressing issues of social experience, class, race, gender or politics of space as well as theories of the body, of mobility and such like.

Strategies can also be read as paradigms of probability in order to shift the emphasis away from a description of actual appearances and to focus instead on key ingredients and their probable functioning. In an exploration of creative processes, this invites new sets of questions, for example: what are the underlying principles of this or that approach? The focus would shift from a predominantly visual or themed description of a practice as in the case of history painting or landscape painting, towards the naming of underlying concerns and artistic intentions.

I will now turn towards some examples of classification in other art forms, which seem to correspond to a naming of strategies and which indicate artistic intentions and methodologies. In a defining article in Cahiers du Cinéma from 1954, the French film-maker, François Truffaut promoted the notion of 'auteur cinema' in 
order to encourage directors to realize very personal and creative visions in their work. Truffaut was part of a group of film-makers, who were taking a stand against the dominant commercial European film industries and against Hollywood, which favoured conventional film-making for the purpose of entertainment. The title auteur cinema reflects the idea that directors should be making films in the way that writers use their pen and not be bound by industry conventions and market forces. The term signals a methodology which rebels against dominant cinematic conventions of the film industry and calls for artistic freedom and diversity. Aiming to support artistic agency over and above style or external pressures and conventions is the kind of strategy that Nellhaus advocates.

In the visual arts there has been a related debate on the question of authorship, spurred by literature such as the seminal essay from Roland Barthes entitled 'The Death of the Author' (Barthes 1977: 142-148). Barthes's essay argued against an emphasis on authorship, critiquing the idea of the author as origin and proposing that it was language and the text that formed the author in the process of writing. Accordingly, the reader was the one who made meaning. Visual artists used Barthes's essay to critique a modernist art market, which promoted and celebrated the artist's genius as the origin of the work.

In search of other models of practice visual artists turned to anthropology and its tradition of field studies, whereby the individual researcher goes out into a specific cultural context and gathers and records information. Traditionally, anthropology privileged a neutral observer and his/her gathering and recording of information was considered to be 'the work'. In an encounter with contemporary art practices, both art and anthropology benefited from raising questions about the nature of representation and subjectivity. Contemporary anthropology favours a more engaged and 
personalized role of the anthropologist, while the visual artist was re-conceived as participant-observer, a shift, which the theorist Hal Foster described as the 'ethnographic turn' in contemporary art. ${ }^{3}$ It was a radical step away from the notion of the artist as the origin of the work and allowed for the development of a completely different kind of art practice.

In addition to 'the artist as anthropologist' concept, artists developed another form of practice, which challenged notions of authorship and which has come to be known as 'appropriation art'. As the term suggests, artists explicitly take, borrow and steal work from other artists and cultural agents and appropriate already existing work, presenting it as their own. Flourishing in the 1970s, its paradigm continues to inform contemporary art practice as well as curatorial projects such as the 2006 Tate Triennial (Tate Britain 2006).

Appropriation art is an example of an artistic strategy that is strongly motivated by a struggle for creative agency, in this case trying to subvert the hero politics at the heart of art institutions, critiquing commercial pressures on artists to be productive, as well as questioning the whole idea of 'making' in art with its link to traditional notions of craftsmanship. Appropriation art answered to an artistic need to challenge a wider context as well as one's own position and to re-invent one's practice.

Terms such as auteur cinema, art as anthropology and appropriation art suggest that Nellhaus's notion of strategy has some mileage, in that these strategies contain useful information on critical approaches to distinctive historical conditions. Practices which come under the term of screendance should also be read as responses to particular tensions and it ought to be possible to identify these practices through the strategies they have developed. 


\section{A knowledge map for 'dance as film'}

In order to explore what Amy Greenfield meant by 'kinaesthetic impact and meanings of dance', I propose a map which draws on all the aspects of this hybrid practice and on choreographic forms of mapping for doing so. I propose a variation of what is known as the Laban effort graph, a visual representation of a possible range of movement qualities or efforts, developed in the 1920s and subsequent decades by Rudolf Laban as part of a wider system for dance notation. His graph allows movement of the live body to be represented in terms of its uses of weight, time, space and flow. In order to map screendance practices, the categories of time, space and weight will be adapted to indicate screen time, screen space and bodies on screen. Within these categories, the graph distinguishes between:

- Real time/duration versus edited time

- Real space versus edited space

- Body as site versus body as tool

The polarities of real time and edited time and their equivalent in space define the parameters for a screenspace, which could be produced through any combination of choreographic and cinematographic means. The polarity between body as site and body as tool is based on the premise that languages of the body are of different provenance. On one hand, there are movement vocabulary and styles which bodies appropriate in the everyday and which may be more or less conscious and likely to be relatively specific to the individual, the family and their social environment. An artist may work with this kind of movement much like he/she may explore a particular location as in the case of so-called site-specific or site-sensitive work. Accordingly, this polarity is named 'body as site'. 
At the opposite pole are formal and precisely rehearsed movement languages such as Bharatnatyam or ballet, which train and shape the body to represent particular concepts and to embody their aesthetics. In this case the body is predominantly a tool in the hands of the artist. A number of contemporary dance styles would for example fall somewhere in between these poles, facilitating an individual flow of movement whilst maximizing its potential through training.

The graph therefore distinguishes between an observational approach in 'body as site' and a directorial approach in 'body as tool'. The graph is shown in Figure 3.

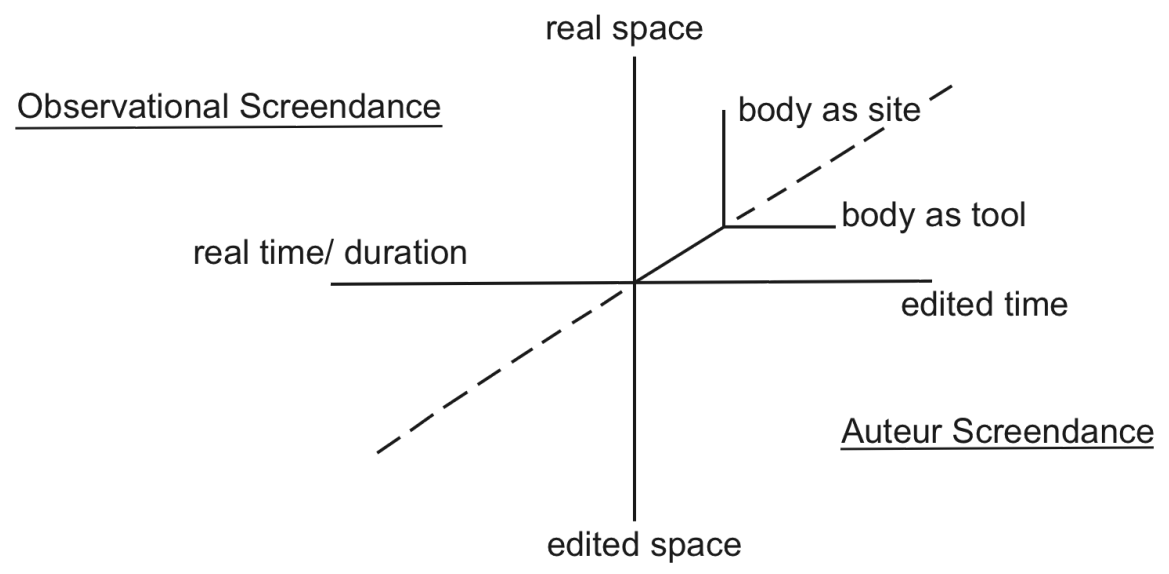

Figure 3: Screendance effort graph.

In this graph, different kinds of space-time and motion can be differentiated in terms of that which is specifically created versus that which is observed or 'found', to borrow another term from the visual arts with its tradition of found objects or readymades. Found material, that is elements collected in real time and real space with a focus on movements of the everyday and pedestrian situations, would, perhaps, be the preferred language for the anthropologist-artist-choreographer. The body as tool as well as edited space-time fragments could be the preferred material for author-led and explicitly choreographed screendance. The two approaches of the observational 
choreographer and the author-led screendance could divide the graph between themselves (see Figure 4).

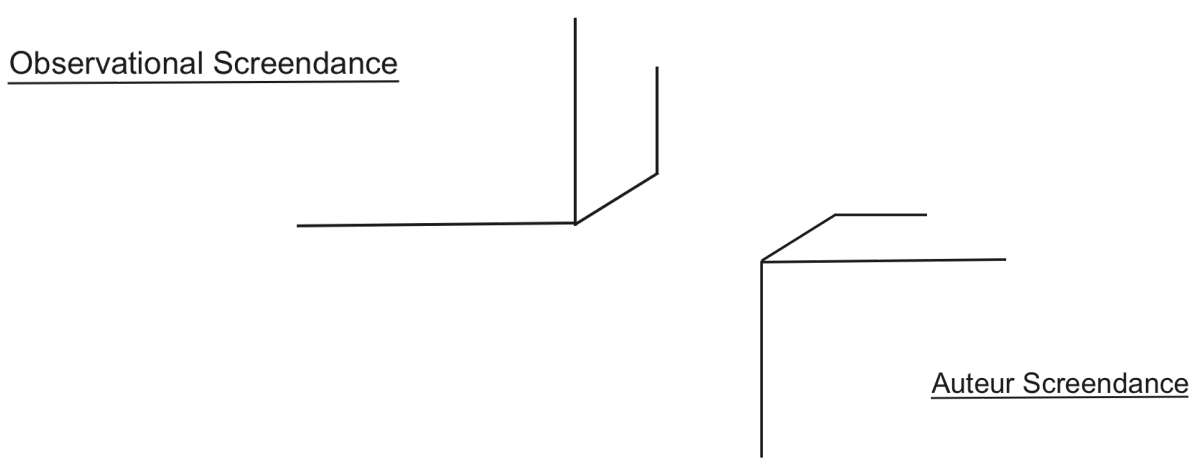

Figure 4: Screen Effort Graph, divided.

The above is a first draft of a graph which integrates diverse screen-based practices such as video art and classic Hollywood realism whilst also mapping potential uses of the body and choreographic methodologies over the whole field. Perhaps the most useful aspect of the graph at this point is that it does away with the existing associations of screendance with either cinema in 'cinedance' or video art in 'videodance', terms which seem too broad, descriptive and vague to identify artistic agencies. However, the above mapping is too basic to account for the complexities of existing choreographic strategies which do not just fall into two distinct areas of practice, but use, match and mismatch any of the applications of space, time and the body.

An observational emphasis in the practice of, for example, video artist Becky Edmunds does not fit neatly into the upper left part of the graph. While Edmunds collects fragments of real time, real space and pedestrian movements, these are composed and edited rigorously to create work that is subjective and personal. Furthermore, the initial observational processes are influenced by an improvisational practice derived from dance, evidenced by Edmund's physical engagement with place 
and her process of framing. An element of movement training would need to be taken into account, although in this case on the part of the one who is behind the camera. The overall feel of the work, such as El Fuego (Edmunds 2007a) is not so much documentary as a series of intimate encounters and a personal testimony. To find a name for this hybrid strategy, which combines the observed and the constructed, one could perhaps create a term like 'real-time choreography'.

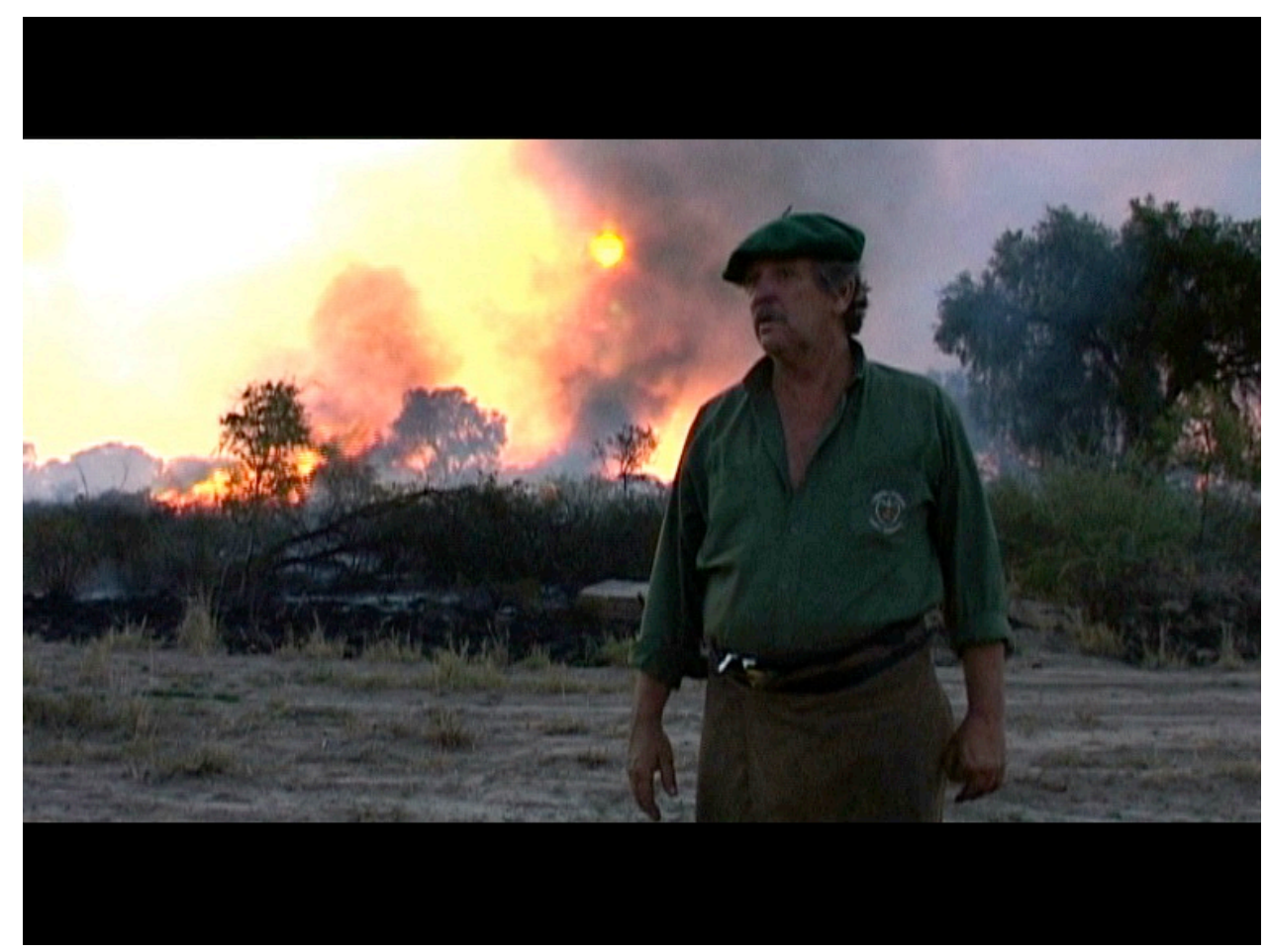

Figure 5: Screen shot of El Fuego (Edmunds 2007a).

The work of film-maker Lucy Cash performs another kind of complexity. The intention of her work is reminiscent of portraiture and unfolds like an anthropological enquiry. However, the work does not build on real time and space, but on small and precisely staged fragments, which are repeated and accumulated in the editing to create continuity and meaning over the course of the work as, for example, in Requiem for the Redheads (Cash 2007a), or Sight Reading (Cash 2007b). 
Cash builds a screen-based chronology, in which rhythm and motion are created in the editing process, a methodology, which Amy Greenfield described with regards to her own films:

I learned that composing time, not in the way that dance steps are accomplished live, but in terms of constructing new connections, new rhythms, new motions through the exact, rhythmic editing of lengths of film, was at the heart of filmdance choreography. Both space and time were released from chronology, and another chronology could be made.

(Greenfield 1983: 26)

Amy Greenfield's piece Element (Greenfield 1973) and much of her other works are based on intense physicality and the cinematic repetition of movement reinforces a sense of process and duration in the work. While much of the filmed material comes out of close encounters between the camera and her as performer, the 'dance' is built over the course of the production and on screen. This partial suspension of the properties of real time, real space and real bodies in favour of a constructed screen world correlates with montage techniques which form the basis of much of the twentieth-century cinema. Montage is used to describe both an assembly of complementary shots as well as the more specific technique of combining juxtaposing shots as developed by Eisenstein.

As this term is, however, suggestive of a mechanical process it may be useful to develop a different term which recognizes a choreographic genealogy. Drawing on Greenfield's statement of a 'release from chronology' it may be more appropriate to call this approach 'release film' to emphasize the choreographic approach to editing in the work of, for example, Greenfield or Cash. ${ }^{5}$ 


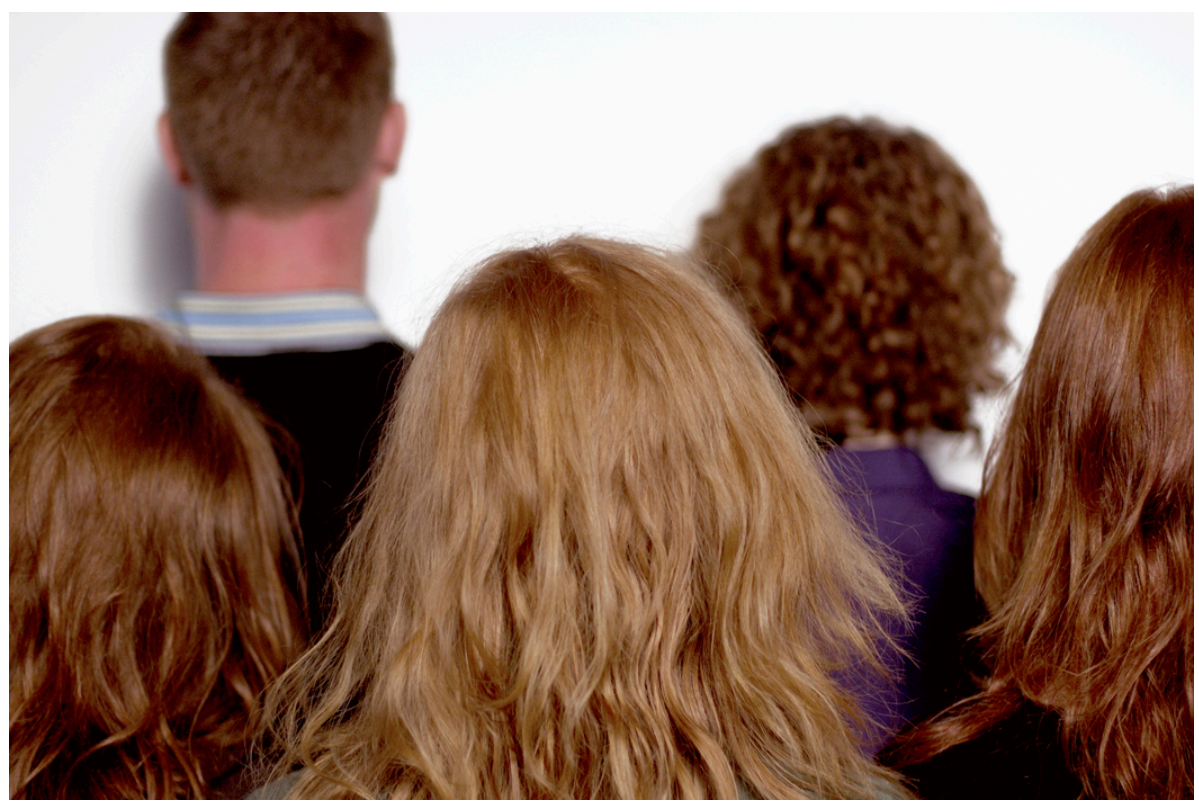

Figure 6: Screen shot of Requiem for the Redheads (Cash 2007a).

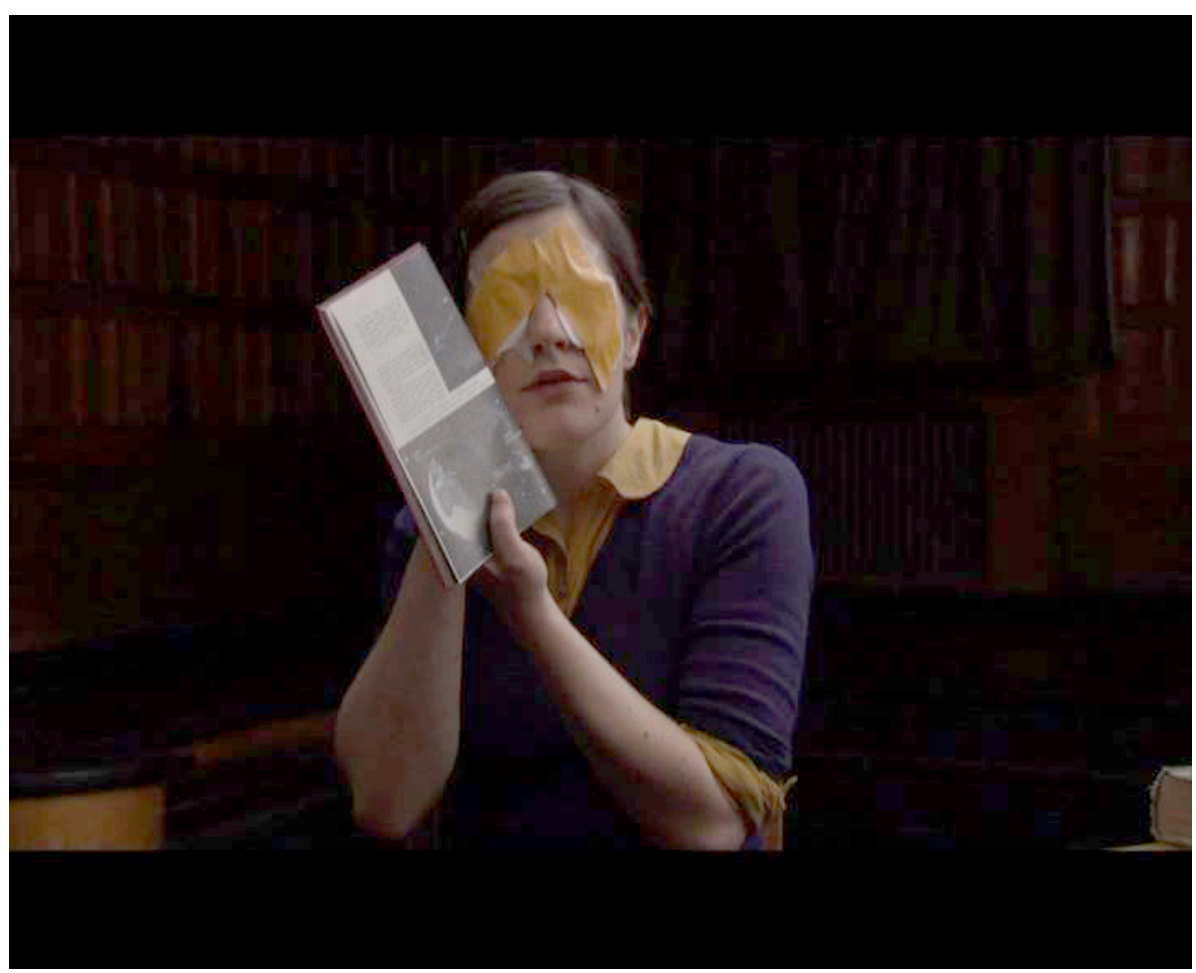

Figure 7: Screen shot of Sight Reading (Cash 2007b). 
Differences in approach to screendance are numerous and it will be impossible here to cover the whole spectrum or to unravel the complexities of video installation, multi-media performance and computer-generated work. I will only mention an intriguing hybrid between analogue and digital production which was presented as Hyperdance by Harmony Bench in a paper at the American Dance Festival in 2006. In this form of screendance, material is generally taken from real space and time and manipulated digitally and, in some cases, offered to the viewer in fragments for her or his own online composition. As Bench argues, it thereby offers the possibility to recover a live element, which is irrevocably absent in linear screendance: 'hyperdance recuperates performance for the screen and positions the computer user not only as a viewer/spectator, but as a performer and even co-choreographer' (Bench 2006; 89). Alongside interactive models, this sort of work also pushes technological possibilities to draw compositional structures from the medium itself. The collaborative works of screendance artists Chirstinn Whyte and Jake Messenger could be included here, as their works Trace (2005), Splice (2005), Vector Path (2008) and Binary Form (2009) engage actively with a process of technologization, deconstructing material gained from the live and reconstructing it within the digital domain. The collaborative nature of their work and the compositional structures derived from the digital medium also continue the debates on authorship as part of the work.

Interestingly, it not easy to see where on the Screendance Effort Graph such a strategy should be placed or how it should be drawn. Considering that hyperdance is technology based, should it therefore automatically be part of the edited time and space? This does not reflect the fact that a project may be based on rules and use the digital space like a real space, allowing processes to unfold their own dynamic. It 
suggests that the 'real space' in the graph should rather be called 'continuous space' allowing it to be either real or digital. In addition, screendance strategies such as realtime choreography, release film and hyperdance tend to combine aspects from across the graph and could therefore be indicated through different parts of the field depending on the emphasis on this or that aspect of a particular production.

The terms and their relative representations within the graph serve to indicate the complexities of the artistic methodologies, and it is this complexity which I would like to articulate. The mapping and shifting of choreographic practices across the graph gives a glimpse of choreographic sensibilities as a whole and indicates how they might operate in screen-based work in a combination of moving bodies and moving images. Significantly, the map points to artistic intentions and methodologies without defining too closely the audio-visual-kinaesthetic outcome (Figure 8).

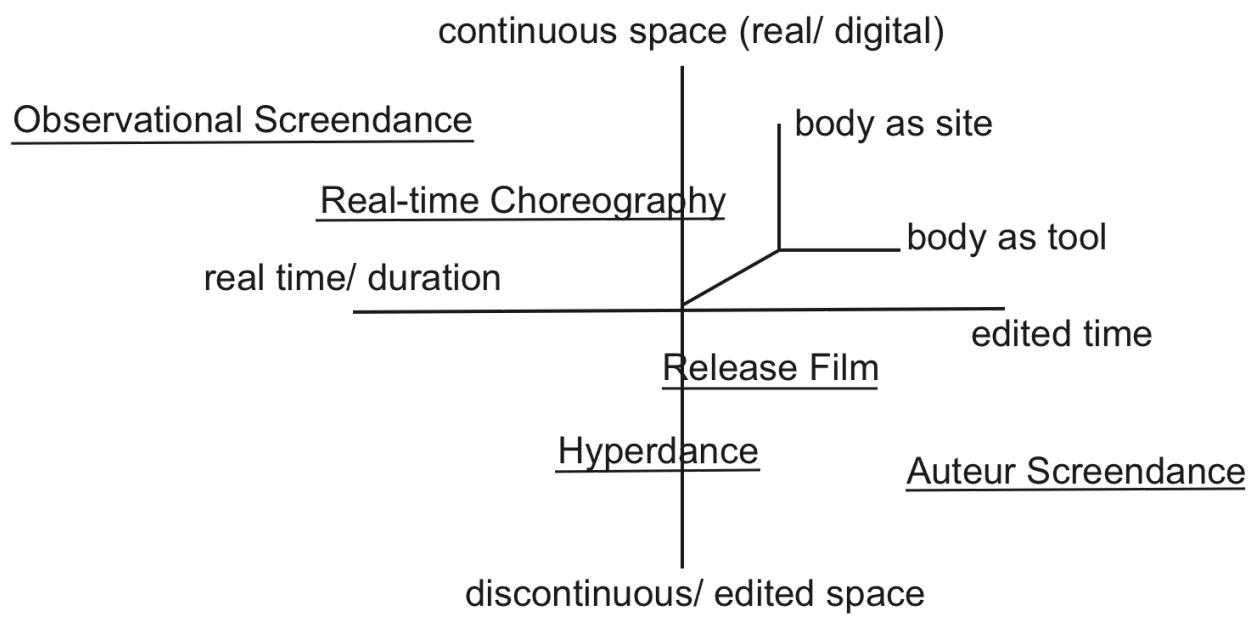

Figure 8: Screendance effort graph with screendance practices.

In mapping specific works it could be useful to distinguish between different processes, such as the acquisition of source material and post-production, indicating one with dotted lines and the other with solid lines (Figure 9 and 10). 


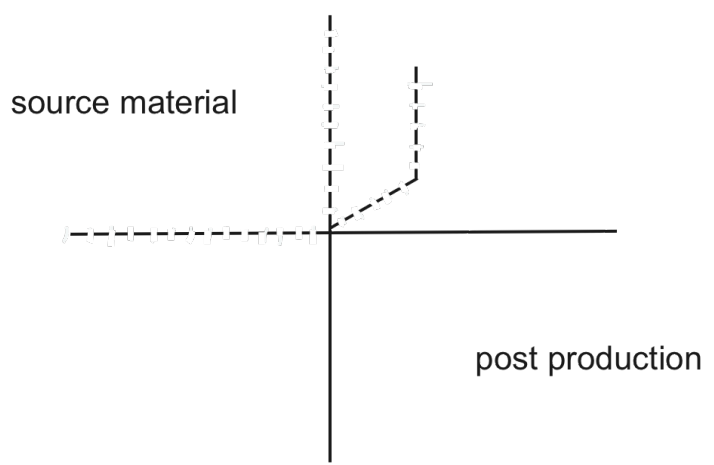

Figure 9: Real-time choreography/ El Fuego (Becky Edmunds 2007b).

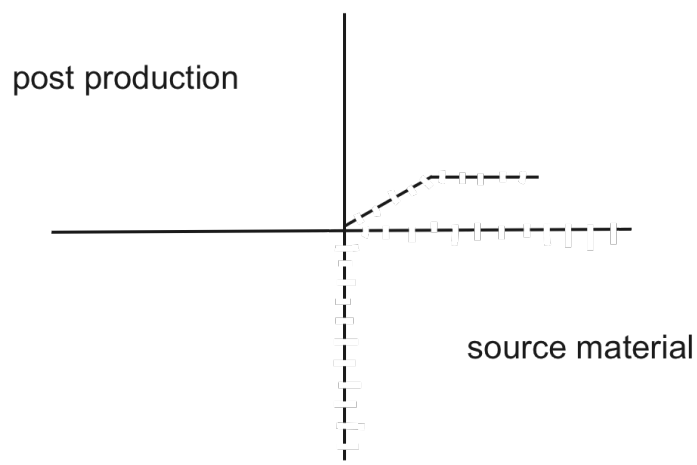

Figure 10: Release Film/ Element (Amy Greenfield 1973).

Reflections on specific and common choreographic strategies in screendance need to be developed further. I make no claims to be comprehensive and the current map does not, for example, represent historical developments or overall tendencies which would also be interesting to explore. The current graph could give the impression of an even distribution or balanced field of practices and I doubt that this is the case. If one were to review a large number of contemporary screendance works, I would anticipate that they fall on the side of auteur screendance. This may be due to a widespread celebration of mobility in contemporary screendance practices in the sense of an excessive display of speed, continuous change and agile bodies. This is no surprise, considering that these qualities can be achieved easily through a combination of moving bodies, moving cameras and editing, but the question remains as to why mobility features so strongly. 
In his analysis of performance practices, Nellhaus uses a term, the 'image schemas', to name unspoken notions of truth which inform a particular cultural field. In his critique of, for example, medieval performance strategies, Nellhaus argues that they are primarily built upon the two image schemas 'Truth is writing' and 'Truth is repetition', the first based on the importance of manuscripts and handwriting in medieval times, the second on oral traditions (Nellhaus 2006: 68). It is likely that most art forms function on the basis of such unspoken image schemas or truth conventions, and the prevalence of mobility in contemporary screendance suggests that the main image schema for contemporary practitioners is something like 'Truth is Movement' or 'Truth is Mobility'. These truths are rooted historically in the fact that dance identified itself with movement when it separated from other arts such as music and scenography. From then on 'to dance was to move', a credo which also corresponded to a wider modernist agenda and which was reflected further in the advent of film.

Maya Deren noted that the invention of the filmic apparatus with its construction of space and time coincided with the formulation of the theory of relativity. She argued that "the formal as well as philosophical concepts of [the filmmaker's] age are implicit in the actual structure of his instrument and the techniques of his medium'. She saw it as the main task of the artist-film-maker, not just to record but also to 'create a total experience $[\ldots]$ out of the very nature of the instrument as to be inseparable from its means' (Deren 1960b: 167). Deren addresses the fact that film is not only a recording device and that experience, and reality, in the twentieth century is understood as a construct and not given. Instead, moving image technologies allow for a creation of space and time unlike those of the everyday and are capable of creating meaning according to their own condition. With this reciprocity between the 
technical apparatus of the moving image and the modern world, cinematographic practices are well equipped to both represent and critique the structures, dynamics and discourses of the twentieth and twenty-first centuries. Screendance offers the same potential and carries the same responsibility. If anything, screendance is doubly obligated through the combination of moving images with moving bodies. Too often screendance displays a rejection of boundaries, seeking instead an unconditional space of no origin and the suggestion of total possibility. The implications here for the representation of, for example, subjecthood are a foregrounding of autonomy, freedom and mastery, leaving behind their counterparts such as dependency, relatedness and failure. ${ }^{6}$ An ongoing idealization of mobility in the art form should be viewed with suspicion, and screendance needs to be critical of its own paradigms if it wants to exert a critical function.

The privileging of mobility in screendance could be represented in the graph through a distortion of the map as a whole, such as a tipping of the graph in space, so that it appears as slippery slope rather than as balanced field (Figure 11).

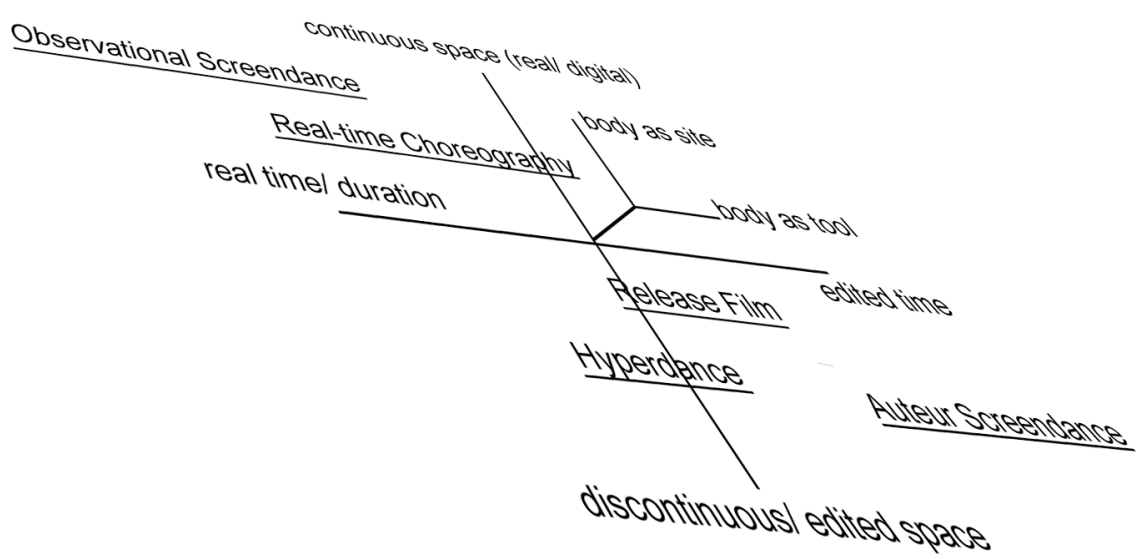

Figure 11: Screendance effort graph, distorted. 
With such a distortion the graph indicates the preference for timelessness, unconditional spaces and autonomous bodies. At the same time, a distorted graph may suggest a need to resist this kind of homogeneity and to seek alternative forms of representation, pointing to less populated parts of the graph for possible methodologies

To conclude, the Screendance Effort Graph offers a possibility of mapping 'dance as film' without prescribing aesthetic forms or limiting the range of possibilities. The map is suggestive of alliances across disciplines and historical trajectories and paying heed to the hybridity of the art form. Only a few markers have so far been placed on the map and many more could be envisaged to develop our knowledge of the field to further the diversification of screendance practices and challenge existing methodologies. A more detailed mapping of the art form would empower artists to stake their claim and to seek new territories. As a practice within a complex field of tensions, the full potential of screendance is still to be explored.

\footnotetext{
${ }^{1}$ Knowledge mapping was used at Opensource \{Videodance\} 2007, a tool developed by Prof. Tom Inns (University of Dundee), that facilitates the visualization of knowledge and the formation of ideas and concepts (Opensource \{Videodance\} 2009:14).

${ }^{2}$ It is impossible here to detail the varied approaches and visual and movement languages developed by these artists, but the list evidences an extensive history of an artistic pursuit, which we have come to identify as screendance.

${ }^{3}$ For further reference see the conference 'Fieldworks: Dialogues between art and anthropology', London: Tate Modern, September 2003, http://www.tate.org.uk/modern/eventseducation/fieldworks.htm. Accessed 6 April 2008. ${ }^{4} \mathrm{~A}$ suggestion of a personal style or 'signature' in the camera work and editing would be interesting but difficult to substantiate. For a discussion on signatures as 'corporeal writing' see Ann Cooper Albright's essay on Loie Fuller mentioned above. While Cooper Albright applies the notion of 'corporeal writing' to concrete outlines and relative immediate traces of bodies, we could also consider extending this concept to include/incorporate movements of a physically manipulated camera or particular editing styles (Cooper Albright 2006: 28).

${ }^{5}$ Lev Manovich discusses the history of montage techniques as part of a debate on compositing as computer-based authorship. Compositing refers particularly to the digital environment and the building up of images through layers, which again seems to be different to a movement-based approach (Manovich 2001: 141-145).
} 
${ }^{6}$ An extensive debate on the privileging of the autonomous individual in modernity can be found in Teresa Brennan's publication Exhausting Modernity, Grounds for a New Economy (Brennan 2000: 21-40).

\section{References}

Barthes, R. (1977), 'The death of the author', Image-Music-Text, London: Fontana, pp. $142-148$.

Bench, H. (2006), 'Hyperdance: dance onscreen, dance online, or, what difference does the medium make?' Proceedings ADF (American Dance Festival) Screendance State of the Art 1, 6-9 July, Durham, NC: Duke University, pp. 89-94.

Brennan, T. (2000), Exhausting Modernity, Grounds for a New Economy, London: Routledge.

Cash, Lucy (2007a), Requiem for the Redheads.

- (2007b), Sight Reading.

Chiba Sterns, Jeff (2007), Yellow Sticky Notes.

Clair, René (1924), Entr'Acte, France: Société Nouvelle des Acacias.

Cooper Albright, A. (2006), 'Resurrecting the future', Proceedings ADF (American

Dance Festival) Screendance State of the Art 1, 6-9 July, Durham, NC: Duke University, p. 27.

Deren, M. (1960a), 'Cinema as an art form', in L. Jacobs (ed.), Introduction to the Art of the Movies, New York: Noonday, p. 258.

— (1960b), 'Cinematography, the creative use of reality', Daedalus, 89: 1, p. 150.

Dodds, S. (2001), Dance on Screen: Genres and Media from Hollywood to

Experimental Art, London and New York: Palgrave.

Edmunds, Becky (2007a), On the Surface.

- (2007b), El Fuego. 
'Fieldworks: dialogues between art and anthropology', (2003) London: Tate Modern, http://www.tate.org.uk/modern/eventseducation/fieldworks.htm. Accessed 6 April 2008.

Fildes, S. (ed.) (2009), Opensource: \{videodance\}, Findhorn: Goat Media Limited, p. 14.

Foster, H. (1999), 'The artists as ethnographer', in H. Foster (ed.), The Return of the Real, Cambridge, MA: MIT Press, pp. 171-203.

Fuller, Loïe (1921), Le Lys de la Vie, France: Société des Etablissements L. Gaumont. Gottschalk, Bert (2007), Framing/Fensterbilder.

Greenfield, A. (1983), ‘Artist statement', Filmdance Festival Catalogue, New York City: Public Theatre, p. 26.

Greenfield, Amy (1973), Element.

Manovich, L. (2001), The Language of New Media, Cambridge: MIT Press, pp. 141145.

Martin, R. (1998), Critical Moves, Durham and London: Duke University Press, p. 6. Nellhaus, T. (2006), 'Critical realism and performance strategies', in D. Krasner and D.Z. Saltz (eds.), Staging Philosophy, Michigan, MI: University of Michigan Press, pp. $57-85$.

Newlove, J. and Dalby, John (2003), Laban for All, London: Nick Hern Books, pp. $151-158$.

Rosenberg, D. (2006), 'Proposing a theory of screendance', Proceedings ADF (American Dance Festival) Screendance State of the Art 1, 6-9 July, Durham, NC: Duke University, pp. 15, 16.

Sanchez, J.A. and de Navaran, I. (2008), 'Editorial Cuerpo y cinematografía', Cairon 11, pp. 237, 238.

Steel, Christopher (2008), Welcome to Southside. 
Tate Britain (2006), Tate Triennial, 1 March-14 May 2006,

http://www.tate.org.uk/britain/exhibitions/triennial. Accessed 7 September 2009.

Truffaut, F. (1954). 'Une certaine tendance du cinéma français', Cahiers du Cinema,

31, pp. 15-29.

Vaccarino, E. (1997), 'Dance and video', Ballet.

Whyte, Chirstinn (2005), Trace, London: Shiftwork.

- (2008), Vector Path.

(2009), Binary Form.

Winans, Jamin (2005), Spin.

\section{Contributor details}

Claudia Kappenberg danced professionally in Europe and New Zealand and completed an M.A. Fine at the Central Saint Martins College of Art and Design in 1998. She is a Senior Lecturer in Performance and Visual Art at the University of Brighton, UK and Course leader for the MA Performance and Visual Practices. Her projects comprise single screen work as well as screen-based installations and live site-specific events and have been shown across Europe, the United States and the Middle East. Claudia leads an AHRC Screendance Network with UK- and US-based scholars and practitioners and is Co-Founder and Editor of the International Journal of Screendance.

E-mail: C.Kappenberg@brighton.ac.uk 